\title{
FREE AMINO ACIDS IN THE HUMAN AQUEOUS HUMOUR*
}

\author{
BY \\ C. WUŃDERLY and B. CAGIANUT
}

From the Ophthalmological Clinic (Director: Prof. Marc Amsier) and the Medical Clinic (Director: Prof. W. Löffler), University of Zürich

THE method of two-dimensional paper chromatography has enlarged and enriched our knowledge of the existence and concentration of free amino acids in the human aqueous humour. The comparison of numerous analytical data provides information regarding permeability and the competitive inhibition in the protein metabolism of the surrounding ocular media, under normal and pathological conditions.

The small volume of aqueous humour in each eye makes the qualitative characterization of free amino acids a much more difficult problem than in other body fluids. The determination of alpha-aminonitrogen becomes impossible because the entire aqueous humour available in the single case has to be collected by drops. Likewise, inorganic ions cannot be removed by the well-known procedure of electrolysis and of ion exchange resins. Furthermore, it is necessary first to eliminate the proteins of inflammatory aqueous humour with ethanol. Other ninhydrin positive substances are not easily separable, and the hydrolysis of peptides, if present, creates another technical problem.

\section{Analytical Methods}

Considering all these handicaps, we adopted the following technique:

The aqueous humour, deproteinized with ethanol, is spread out entirely on a sheet of Whatman paper No. $1(40 \times 40 \mathrm{~cm}$.); the surface covered, a circle $1 \mathrm{~cm}$. in diameter, is situated $10 \mathrm{~cm}$. from the right and $6 \mathrm{~cm}$. from the lower margin of the sheet. After the starting circle has been air-dried, it is moistened with $5 \mu l$. of a fresh solution of 35 per cent. $\mathrm{H}_{2} \mathrm{O}_{2}$ containing $0 \cdot 1$ per cent. of ammonium molybdate applied from a micropipette. The first run moves upward, using the liquid mixture of $n$-propanol and water in the proportion of 7:3 (volume fractions; see Pernis and Wunderly, 1953). After about $28 \mathrm{hrs,}$ the solvent front has attained the line which passes at $33 \mathrm{~cm}$. from the lower edge of the sheet. The paper is taken from the trough and air-dried within 20 minutes. The second run moves downward and is developed with phenol saturated with water. In every corner of the trough we place one drop of 25 per cent. ammonia; on its bottom there is a dish filled with water saturated with phenol. After $15 \mathrm{hrs}$ (at $17^{\circ} \mathrm{C}$.), the paper is carefully removed and hung in a wooden trough, where it is dried for $3 \mathrm{hrs}$ in an electrically preheated draught. The temperature within the wooden trough must not rise above $45^{\circ} \mathrm{C}$. For the ninhydrin reaction we used the method of Moore and Stein (1948); the buffer solution contains $13.3 \mathrm{~g}$. citric acid, $100 \mathrm{ml}$. $\mathrm{n} \mathrm{NaOH}, 400 \mathrm{mg}$. $\mathrm{SnCl}_{2}+\mathrm{S} \mathrm{H}_{2} \mathrm{O}$ and water up to $250 \mathrm{ml}$. Under cover of paraffin oil, this solution remains stable for 2 weeks. The solution of ninhydrin contains $4 \mathrm{~g}$. of the substancet dissolved in $100 \mathrm{ml}$. methylcellosolve. Shortly before use, equal volumes of both liquids are mixed and placed in icewater; subsequently, $1.5 \mathrm{ml}$. of this mixture is evenly sprayed on the chromatogram by compressed air, and the sheet is hung for 15 mins. in a thermostat at $60^{\circ} \mathrm{C}$ exactly, in order to develop the colours.

*Received for publication December 2, 1953. +F. Hoffman-La Roche, Basel. 
To obtain the positive identification of the coloured spots according to their $R_{F}$ values. - We prepared several control chromatograms, using a mixture of glycine, alanine, glutamic acid, histidine, and valine*. On the chromatograms of aqueous humour, only the histidine spot showed a certain fluctuation of the $R_{F}$ value; considering its direction, we deduced the possible contamination of lysine and glutamine, but, as explained before, we were not able to effect a closer characterization. It is possible to discuss the quantities of the amino acids established, since Pratt and Auclair (1948) communicated the minima which may be observed by this method. These are: glycine $0.1 \mu \mathrm{g}$.; alanine $0.2 \mu \mathrm{g}$; ; valine $0.2 \mu \mathrm{g}$.; leucine $0 \cdot 5 \mu \mathrm{g}$.; threonine $2 \mu \mathrm{g}$.; glutamic acid $0 \cdot 1 \mu \mathrm{g}$.; tyrosine $3 \mu \mathrm{g}$.; phenylalanine $5 \mu \mathrm{g}$; methionine $1 \mu \mathrm{g}$. On an average, the coloured spots were so small that they cannot be very different from the levels mentioned, with the sole exception of alanine, the value of which was considerably higher. We shall also add some threshold values of perception for the amino acids not ascertained, since they may indicate that the substances in question, if present, do not reach the critical concentration: arginine $4 \mu \mathrm{g}$.; asparagine $1 \mu \mathrm{g}$; ; tryptophane $3 \mu \mathrm{g}$; ; proline $1 \mu \mathrm{g}$.; taurine $1 \mu \mathrm{g}$. Estimating the volume of the aqueous humour available for analysis at $0.2 \mathrm{ml}$; it contains at least $0.5 \mu \mathrm{g}$. glycine $\mathrm{per} / \mathrm{ml}$. when the chromatography-shows a glycine coloured spot; i.e., the glycine concentration of the aqueous humour is about 40-90 times less than that of normal serum; the same proportion is found in the other free amino acids (Table I). It is of interest to add that the proportion of proteins between the normal blood-serum and the normal spinal fluid is also about $1: 80$.

TABLE I

DISTRIBUTION OF FREE AMINO ACIDS IN 27 PATIENTS

\begin{tabular}{|c|c|c|c|}
\hline Free Amino Acids & $\begin{array}{c}\text { Normal Serum } \\
(\mu \mathrm{gg} / \mathrm{ml} .) \\
1 \mu \mathrm{g} . \times 0.001 \mathrm{mg} .\end{array}$ & Number of Patients & $\begin{array}{l}\text { Percentage of } 27 \\
\text { Chromatograms }\end{array}$ \\
\hline Glycine & & 3 & 11 \\
\hline Alanine & $20-47$ & 24 & 88 \\
\hline Valine* & $20-37$ & 11 & 41 \\
\hline Leucine* & $15-23$ & 7 & 26 \\
\hline Serine & & 11 & 41 \\
\hline Threonine* & $15-26$ & 2 & 7 \\
\hline Glutamine & & 3 & 11 \\
\hline Histidine* & $19-21$ & & \\
\hline Lysiné & $23-31$ & 11 & 41 \\
\hline Tyrosine & $10-17$ & 1 & 4 \\
\hline Phenylalanine* & $8-20$ & 1 & 4 \\
\hline Methionine* & $1,8-5,4$ & 7 & 26 \\
\hline
\end{tabular}

* F. Hoffman-La Roche, Basjel. 


\section{Clinical Results}

We examined 33 patients with different ophthalmic diseases. In 27 cases (82 per cent.) it was possible to ascertain by chromatography the existence of free amino acids, which were distributed as follows:

(1) The first group (Table II) comprised four cases of disease of the posterior ocular segment, in which the aqueous humour, seen with the slit lamp and in the routine investigations after paracentesis, showed no alteration and may be considered normal.

The average content of free amino acids in these speciments is clearly reduced with respect to the serum, and is mostly below the threshold. On the chromatogram, all the aromatic amino acids tend to be absent, and among the aliphatic, the group of the diamino acids is mostly missing as well as glutaminic and aspartic acid, both of which are important for intermediate protein metabolism. Alanine, if present, shows the largest quantities in nearly every case.

TABLE II

FOUR NORMAL CASES

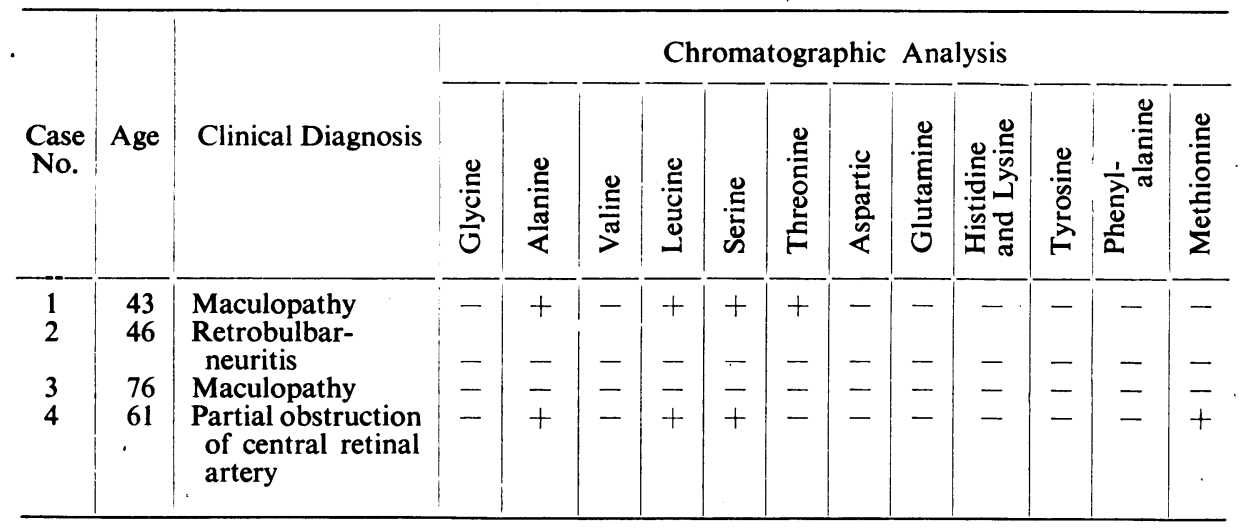

(2) The picture was similar in ten cases of senile cataract (Table III, overleaf). Some free amino acids were occasionally found, among which alanine was most abundant. Nevertheless, most of the amino acids did not reach the threshold or were entirely missing. As a matter of possible interest with regard to the pathogenesis of senile cataract, the frequent presence of sulphur-containing amino acids, such a methionine may be noted; these are rarely found in other types of disease. In this connection, the type of opacification and the evolution of the cataract do not seem to play a significant role.

(3) In three caśes of heterochromic cyclitis (Table IV, overleaf), two with cataract, we nearly always found amino acids of the basic group. These cases can therefore be incorporated within the front of inflammatory diseases of the anterior ocular segment, which in their chromatogram, in addition to the free amino acids normally present, generally show the coloured spots characteristic of diamino acids. It has not been possible, however, to establish a connection with the cytogram, which in all the cases of heterochromic cyclitis disclosed a few degenerate cells.

(4) Most of our cases presented acute or chronic inflammations of the anterior ocular segment, the majoirty being iridocyclitis of various origins. In every case we also established the cytogram, combining both methods of inquiry in order to. obtain information about grading aetiology, prognosis, and treatment (Table V, overleaf). 
TABLE III

NINE CASES OF SENILE CATARACT

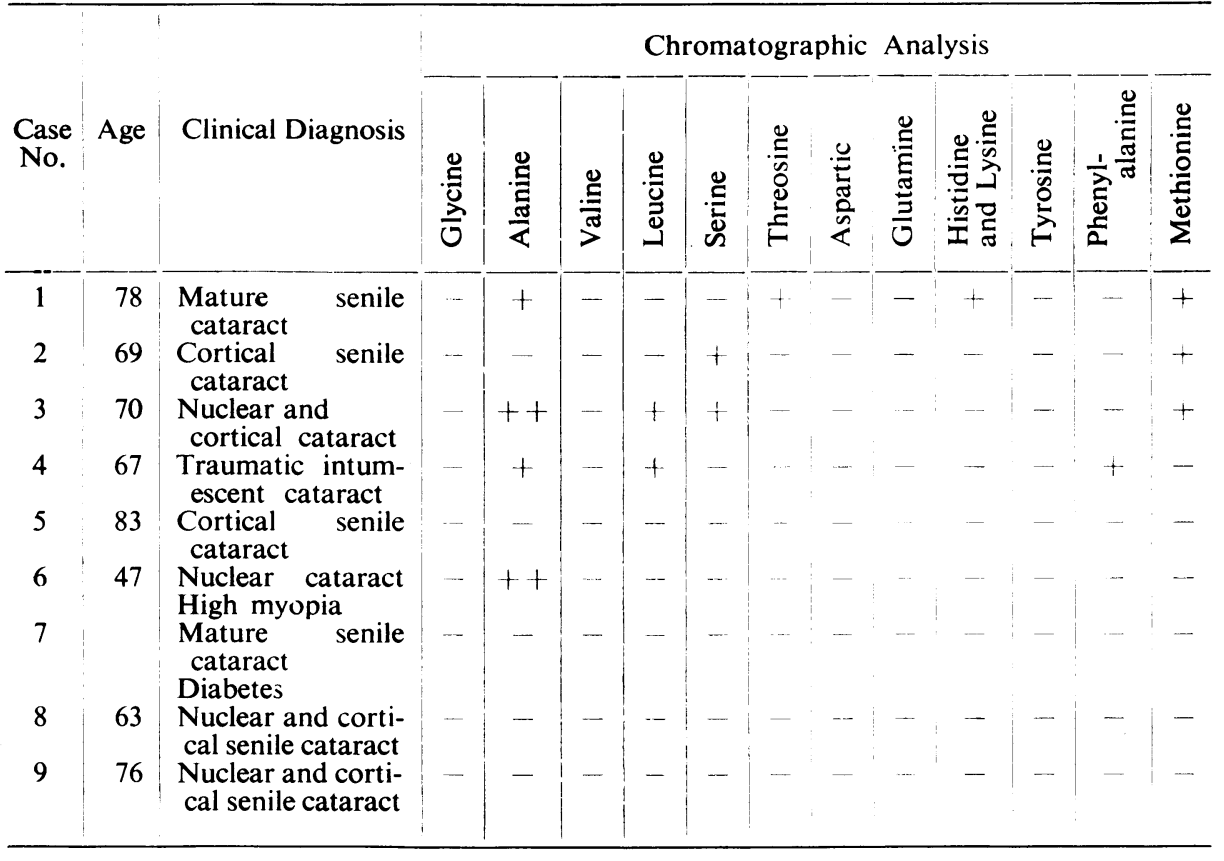

TABLE IV

THREE CASES OF HETEROCHROMIC CYCLITIS

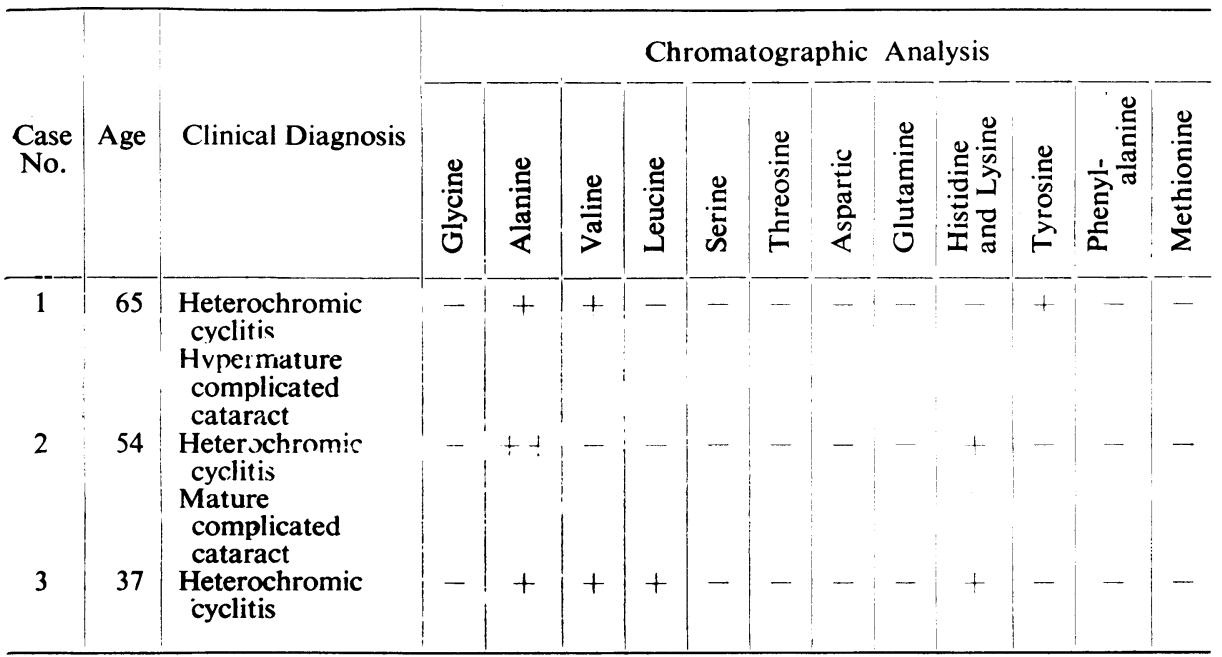

The most prominent characteristic of inflammatory aqueous humour is the increase of the amino acid concentration. Alanine is found in the largest quantities, whereas glutamic acid and histidine are new amino acids the presence of which can be proved in several cases. It is mainly in acute affections that the chromatogram shows an increase of basic amino acids. On the other hand, it has not been 
TABLE V

FOURTEEN CASES OF ANTERIOR UVEITIS

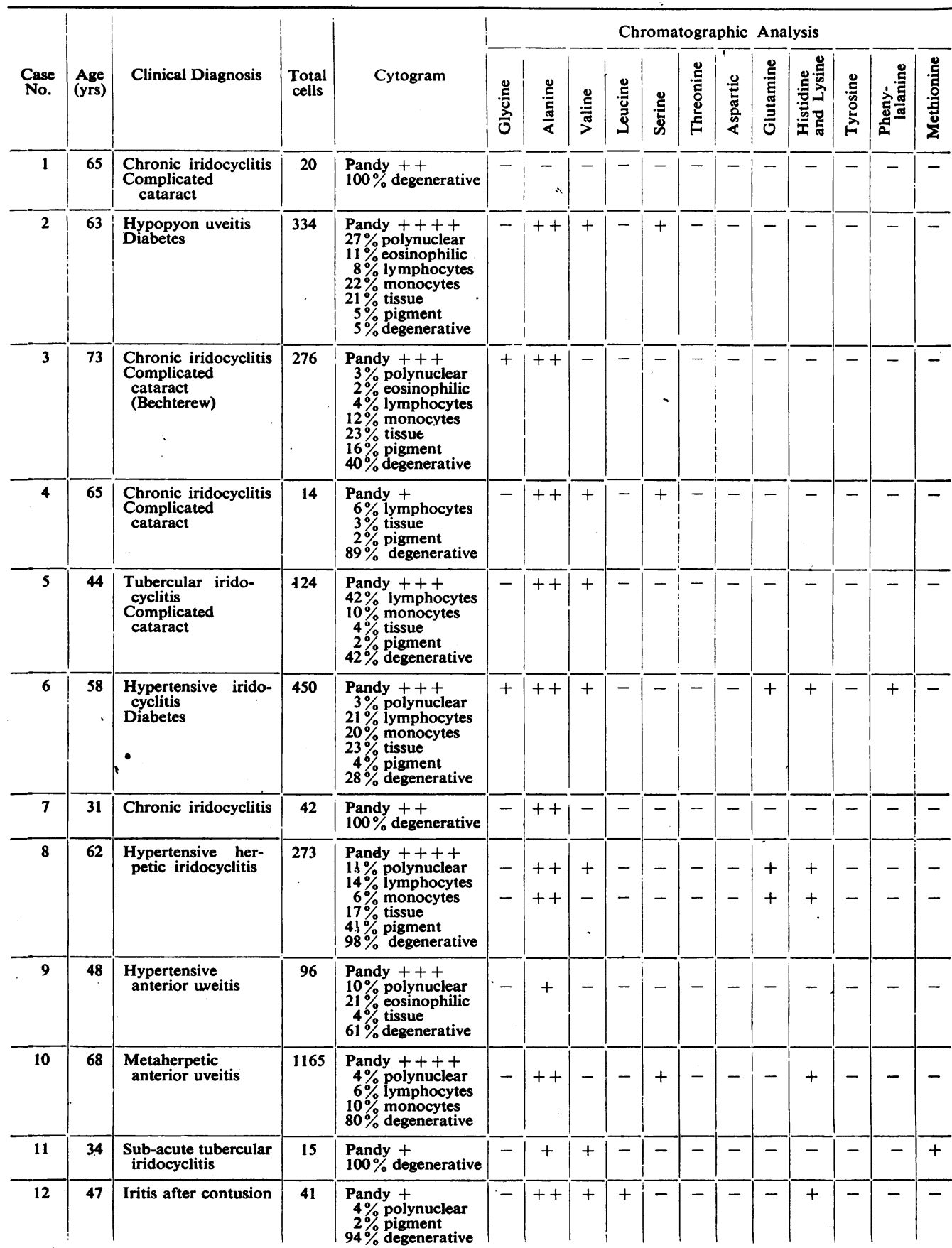


TABLE V-continued

\begin{tabular}{|c|c|c|c|c|c|c|c|c|c|c|c|c|c|c|c|c|}
\hline \multirow[b]{2}{*}{$\begin{array}{l}\text { Case } \\
\text { No. }\end{array}$} & \multirow[b]{2}{*}{$\begin{array}{l}\text { Age } \\
\text { (yrs) }\end{array}$} & \multirow[b]{2}{*}{ Clinical Diagnosis } & \multirow[b]{2}{*}{$\begin{array}{l}\text { Total } \\
\text { cells }\end{array}$} & \multirow[b]{2}{*}{ Cytogram } & \multirow[b]{2}{*}{$\frac{\mathscr{E}}{\stackrel{\Xi}{U}}$} & \multirow[b]{2}{*}{$\stackrel{\stackrel{.}{E}}{\frac{\pi}{2}}$} & \multirow[b]{2}{*}{$\stackrel{\stackrel{\Xi}{\pi}}{>}$} & \multicolumn{4}{|c|}{ Chromatographic } & \multicolumn{2}{|c|}{ Analysis } & \multirow[b]{2}{*}{$\frac{\mathscr{L}}{\frac{E}{5}}$} & \multirow[b]{2}{*}{ 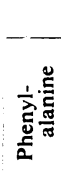 } & \multirow[b]{2}{*}{ 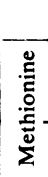 } \\
\hline & & & & & & & & త્气 & $\stackrel{\mathscr{E}}{\mathscr{L}}$ & $\begin{array}{l}\stackrel{U}{\Xi} \\
\text { E } \\
\stackrel{\Xi}{E} \\
\text { E }\end{array}$ & $\frac{0}{3}$ & 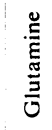 & 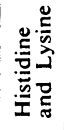 & & & \\
\hline 13 & 33 & Pan-uveitis & 91 & $\begin{array}{l}\text { Pandy }++ \\
25 \% \text { lymphocytes } \\
75 \% \text { degenerative }\end{array}$ & - & ++ & $\cdots$ & -- & + & - & - & 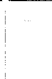 & $\therefore$ & 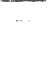 & - & - \\
\hline 14 & 43 & $\begin{array}{l}\text { Tubercular pan- } \\
\text { uveitis }\end{array}$ & 43 & $\begin{array}{l}\text { Pandy }++ \\
10 \% \text { polynuclear } \\
2 \% \text { eosinophilic } \\
4 \% \text { lymphocytes } \\
5 \% \text { monocytes } \\
6 \% \text { tissue } \\
2 \% \text { pigment } \\
71 \% \text { degenerative }\end{array}$ & - & + & + & - & + & - & $\cdots$ & - & + & $\cdots$ & + & - \\
\hline
\end{tabular}

possible to deduce any relation with the aetiology of the disease from the individual chromatograms. In a more chronic process, the chromatogram, even with the increase of its protein contents, tends to adapt itself to the normal configuration; i.e., there is no strict parallelism between the protein level and the concentration of free amino acids.

In two cases ( 6 and 8 , Table $\mathrm{V}$ ) we did repeated punctures without observing any significant modification of the chromatogram. This finding seems to indicate that there is a dynamic equilibrium only displaced in special circumstances; which can be used to discover the presence of metabolic disorders in diseases of the anterior ocular segment (Fig. $1 a$ and $b$ ).

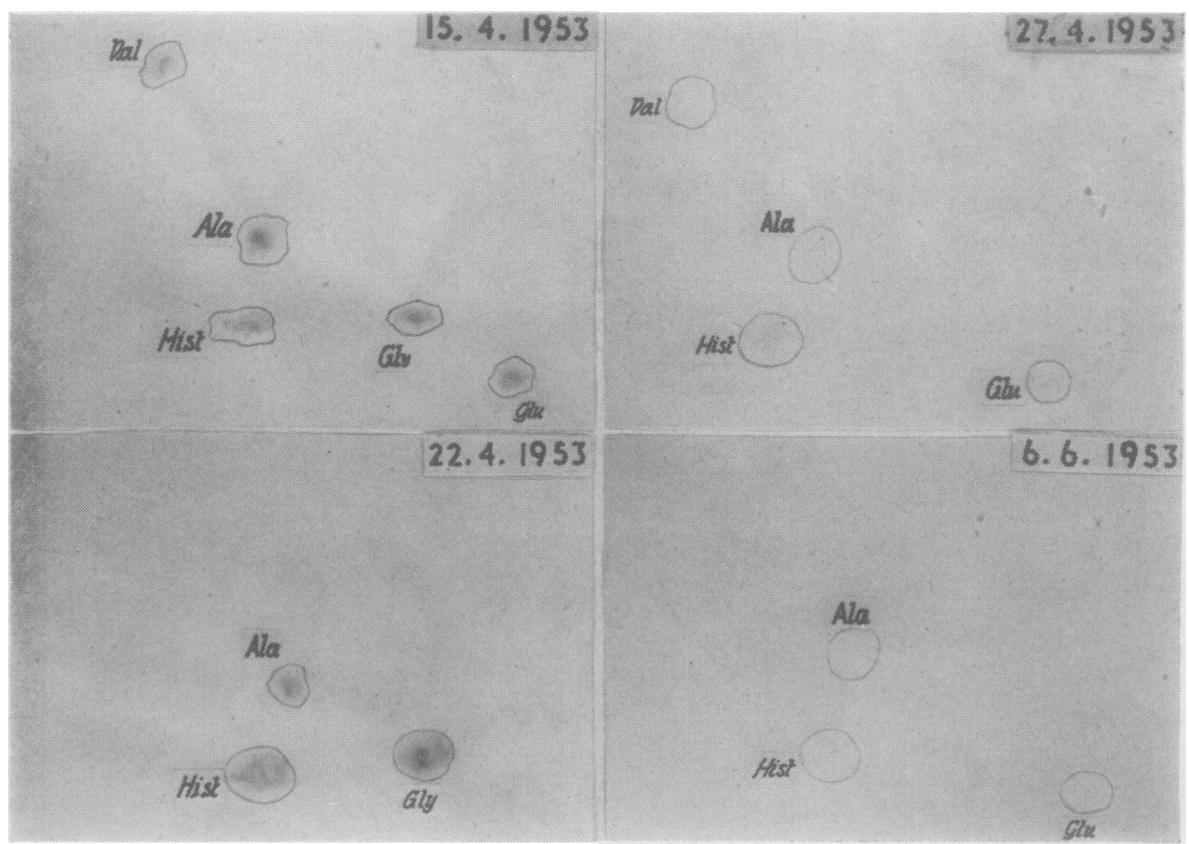

Fig. 1.-Case 6, Table V, hypertensive iridocyclitis.
FIG. 2.-Case 8, Table V, hypertensive herpetic irldocyclitis. 


\section{Discussion}

A comparison of the free amino acids in the aqueous humour with that in other body fluids presents interesting possibilities. The amino acid content in the normal and pathological aqueous humour is less than in the blood serum, some being missing or only present in below-threshold values. This may be explained by the metabolism of the surrounding ocular tissues, among which the ciliary body and the lens seem to be the most important. Unfortunately, as we had no case of uncomplicated aphakia to compare with a phakic eye, we were unable to assess the protein metabolism of the lens.

The spinal fluid also contains free amino acids in much smaller proportions than the blood serum. The single exception to this is glutamine, which is present in equal proportions in both fluids; this substance, together with glutamic acid plays a preponderant role in the metabolism of the brain cells. The chromatographic investigation of the spinal fluid conducted by Boulanger and Biserte (1949) shows that this also contains the following free amino acids: glycine, alanine, valine, serine, leucine, glutamic acid, aspartic acid, and only traces of dibasic amino acids. There is thus at least a good qualitative agreement with the free amino acids we observed in the aqueous humour. As it has been proved that many amino acids cannot traverse the blood-brain barrier, it is possible that this is also the case with the aqueous humour.

The difference between blood plasma and urine in their content of free amino acids is still greater. In the blood plasma we find essential amino acids with higher molecular weight, but normal urine mainly contains those of lower molecular weight. Saliva, according to Berry (1951), contains glycine, alanine, serine, lysine, glutamic acid, and aspartic acid.

\section{Conclusions}

The amino acid content of the normal aqueous humour is considerably lower than that of the blood plasma. Most of the amino acids of the aqueous humour, if present at all, have sub-threshold values. The aliphatic amino acids of low molecular weight predominate, free alanine being the most abundant. In cases of fully-developed cataract, free methionine is frequently present in considerable quantities. The concentrations of free amino acids may be increased by inflammations of the anterior ocular segment, the basic group being prevalent mainly in acute cases. Comparison with blood plasma and other body fluids seems to indicate that the level of amino acids in the aqueous humour is influenced by the metabolism of the surrounding ocular tissues.

\section{REFERENCES}

AMSler, M., and Verrey, F. (1943). Ophthalmologica (Basel), 105, 144.

BerRy, H. K. (1951). Univ. Texas Publ., No. 5109. p. 157.

Boulanger, P., and Biserte, G. (1949). Bull. Soc. Chim. biol. (Paris), 31, 696.

(1951) Ibid., 33, 1930.

DENT, C. E. (9147). Biochem. J., 41, 240.

LENT, (1948). Ibid., 43, 169.

MoOre, S., and SteIN, W. H. (1948). J. Biol. Chem. 176, 367.

Pernis, B., and Wunderly, C. (1953) Biochim. biophys. acta, 11, 209.

PratT, J. I., and Auclair, J. L. (1948). Science, 108, 213.

WaelsCh, H. (1951). Advanc. Protein Chem., 6, 299. 